\title{
Vasyl Pastushenko's Scientific School in the Development of Soil Protection Technologies in Ukraine
}

\author{
Nataliia Kovalenko \\ Institute of History of Agrarian Science, Education and Technology \\ NSAL NAAS \\ Geroiv Oborony 10 \\ Kyiv 03127, Ukraine \\ Email: BoikoNP@ukr.net
}

\begin{abstract}
The article describes the achievements of scientists of the leading scientific school of thought on the development of soil protection technologies in Ukraine, founded by Vasyl Onufriievych Pastushenko (1907-1999). The introduction of the years of the scientists' research in Ukrainian farms with different soil and climatic conditions has resulted in efficient production of quality agricultural products and improvement of environmental conditions, particularly, the improvement of soil protection crop rotations with the cultivation of mixtures of perennial legumes and siderates, anti-erosion cultivation of soil across the slopes, fertilizer and mulching, etc. Among the followers of Vasyl Pastushenko are the well-known scientists P. I. Boiko, V. O. Borodan, V. V. Kulbida, H. K. Medvid, I. H. Predko, I. H. Zakharchenko, and others. The purpose of the article is to review the achievements of these scientists in the development of soil protection, anti-erosion measures in different soil and climatic conditions in Ukraine.
\end{abstract}

Keywords: anti-erosion measures, development, scientific achievements, scientific school, soil protection technologies

One of the decisive factors in the formation and development of any scientific field, including one aimed at agricultural production, is the achievements of scientific schools. Progress in agrarian knowledge in Ukraine has been inextricably linked to the activities of researchers of scientific schools in the fields of soil science, agriculture, crop production, ecology, agrochemistry, etc. 
In agreement with Yu. O. Khramov, S. R. Mykulinskyi, V. I. Onopriienko, V. M. Tkachenko, and M. H. Yaroshevskyi, a scientific school is considered an informal creative community of highly qualified researchers from different generations, led by a prominent scholar (Khramov, 2008, p. 122). Members of a scientific school should be united in common approaches and methods of work in a relevant scientific direction (Mykulinskyi \& Yaroshevskyi, 1977, p. 7). They must have the same work style and progressive knowledge to efficiently solve problems (Kovalenko, 2018, p. 133). A scientific school gains credibility and public recognition by having solid research results (Onopriienko \& Tkachenko, 2010, p. 434). The activity of Vasyl Pastushenko's scientific school has evolved over at least 80-100 years and has included more than 25-30 scientists from 3-4 generations (Kovalenko, 2014a, p. 264).

As evidenced by studies into the history of agrarian science, Vasyl Onufriievych Pastushenko (1907-1999) was distinguished for his progressiveness in scientific knowledge, which led to the establishment of the first scientific school of thought for the development of soil protection and anti-erosion technology in Ukraine (Saiko, Bogovin \& Solodiuk, 2006, p. 246). In particular, he initiated scientific research into the anti-erosion planning of a territory, taking into account different soil and climatic conditions of Ukraine (Vergunov et al., 2016, p. 10). His achievements in the development of soil protection crop rotation have been notable (Boiko, 2003, p. 280). His personal academic achievements and the activities of the researchers of the scientific school have played a key role in the development of soil protection agriculture in different soil and climatic conditions in Ukraine and elsewhere in the world (Kovalenko, 2014b, p. 93). In 1933-2019, over a hundred candidates and doctors of agricultural sciences were trained in the scientific school (Kovalenko, 2014a, p. 302). The scientists have published more than 900 fundamental scientific works.

Vasil Pastushenko was born in Ukraine, in the village of Poli-Berlency in the Vinnytsia region. In 1932, he graduated from the Kharkiv Land Management Institute, in 1937 he completed postgraduate studies at the Ukrainian Research Institute of Hydrotechnology and Land Reclamation, and carried out most of his scientific research in Kyiv. During 1937-1941, he worked as a senior researcher at the Ukrainian Research Institute of Hydrotechnology and Land Reclamation (NA NNT “IZ NAAN”, op. 1-1, c. 174, p. 134). In January 1941, he defended his dissertation for the Candidate of Agricultural Sciences degree in the specialty of agriculture on inner-farm land management in areas of soil erosion (NA NNT "IZ NAAN", op. 1-1, c. 174, p. 135). In 1941-1945, he 
suspended his scientific activities due to hostilities and fought Nazi invaders in active service in the rank of lieutenant colonel. Since 1946, he worked as head of the crop rotation laboratory at the Ukrainian Research Institute of Socialist Agriculture. In April 1950, he was awarded the academic title of senior research fellow in agriculture (NA NNT "IZ NAAN", op. 1-1, c. 174, p. 137).

Working at the Ukrainian Research Institute of Socialist Agriculture (now the national scientific center Institute of Agriculture of NAAS), Candidate of Agricultural Sciences Vasyl Pastushenko first identified effective crop rotations for farms of various specialization, in particular, saturated $40-100 \%$ by grain crops, $10-40 \%$ by industrial crops, $10-60 \%$ by forage and intermediate crops (Kovalenko, 2014a, p. 298). In the 1950s, the scientific school was recognized as Pastushenko introduced new approaches to the theoretical and methodological foundations of soil protection technologies in different soil and climatic conditions of Ukraine (Voloshchuk, Petrenko \& Yatsenko, 2014, p. 69). Researchers established the scientific principles of placing crops in crop rotations-the role of precursors, legumes, black and busy vapors, replanting (Kovalenko, 2014 b, p. 93), the incompatibility phenomenon of crops, allelopathic soil and other biological factors, which inhibited the increase of soil fertility and crop productivity (CDAVO, F. R-27, op. 21, c. 43, pp. 1-51).

Pastushenko also developed a soil protection system to combat soil erosion in eroded lands, including the erosion management of the territory and the introduction of soil protection crop rotations, efficient tillage across the slopes and the use of organic fertilizers (Kovalenko, 2011, p. 29). Effective soil protection technologies were developed to prevent soil salinization and wetting. He also identified effective measures for the creation and conservation of multiyear hay-grazing and pasture lands of high productivity by introducing meadow crop rotation with different saturation of industrial crops (CDAVO, F. R-27, op. 22, c. 514, pp. 41-57). Under the guidance of Pastushenko, systematic research of the nitrogen cycle in the system 'soil-plant-fertilizer-wateratmosphere' using a stable nitrogen isotope ${ }^{15} \mathrm{~N}$, parameters of symbiotic and non-symbiotic nitrogen fixation in field conditions, was introduced for the first time in Ukraine (Kovalenko, 2014b, p. 93). This provided new knowledge about the transformation of nitrogen in this system.

Pastusheko prevented the development of erosion-hazardous soil processes in different soil and climatic conditions of Ukraine. In particular, he directed research to establish the effectiveness of growing perennial grasses in soil protection crop rotations (Pastushenko, 1966, p. 21). This was of great importance for 
the restoration of the soil structure. Structural soils developed physicochemical processes that created favorable water-air and nutrient regimes and provided high and stable yields of crops (Pastushenko, 1952, pp. 8-9).

The scientist determined the effectiveness of soil protection technologies with the application of forestation of watersheds, plantation of forest and fruit and berry strips. It was important for the creation of plowed strips and introduction of science-based crop rotations. Of great importance were the plowing and sowing of agricultural crops across the slopes, afforestation of ravines and their hydrotechnological consolidation (Pastushenko, 1972, p. 112).

Based on the results of many years of research, V. N. Dunaevskyi, V. O. Pastushenko and O. S. Skorokumov proposed a practical implementation of effective soil protection measures. In particular, five-soil crop rotations with two fields of perennial legumes. Of great importance were the seven-soil and ten-soil grassland crop rotations with the cultivation of perennial legumes, post-harvest and after-crops (Skorodumov, Pastushenko \& Dunaievskyi, 1961, p. 98). In their application, two main tasks were solved: preservation of soil from degradation processes and increase of production of quality agricultural products.

In combating soil erosion, Pastushenko assigned great importance to working out effective anti-erosion tillage, which was carried out across the slopes with mulching, as well as harrowing, felling, cultivation, hole drilling, grounding of the soil (Pastushenko, 1958, p. 43). He determined the optimal terms, norms and methods of sowing crops, applying organic and mineral fertilizers, liming acid and gypsum salt in washed soils (Pastushenko, 1959, p. 123).

Cultivation of crop rotations (maize, sunflower, sugar beet) varied in high productivity, but did not protect the soil from wind and water erosion. Whilst sowing crops-cereals and especially perennial grasses-helped minimize water runoff and soil washing, it did not ensure that the rate of production was comparable to the cropping. Therefore, in developing measures for soil protection, Dunaevskyi, Pastushenko and Skorodumov paid considerable attention to selecting high-performance grass mixtures as well as to establishing their anti-erosion resistance (Skorodumov, Pastushenko \& Dunaievskyi, 1961, p. 100).

To reduce soil degradation, Pastushenko determined the effectiveness of alternating mixtures of perennial legumes and cereals, winter and spring cereals 
and legumes in soil protection rotation in different soil and climatic conditions in Ukraine (Pastushenko, 1972, p. 329). In these crop rotations, the effectiveness of cultivation of corn strips alternating with strips of perennial grasses across the slopes was established.

In the 1960s, the most important aspects of creative academic achievements under Pastushenko's lead were the optimization of the structure of sown areas, the development and implementation of science-based crop rotations, soil protection tillage and organo-mineral fertilizers. He found that the increase in yield and quality of agricultural products was driven by favorable conditions for growing crops, among which their precursors and placement in crop rotation played an important role (Kovalenko, 2014b, p. 92), in particular, the grain crops in the Forest Steppe of Ukraine after peas, corn on green mass, clover, sainfoin, and oat mix increased the fertility of the soil, and the yield and quality of grain products (CDAVO, F. R-27, op. 20, c. 234, p. 8). In Polissia, along with the cultivation of perennial legumes and the introduction of manure, the cultivation of lupine on green fertilizer was important (CDAVO, F. R-27, op. 20, c. 442, p. 65). Under Pastushenko's lead, researchers of the scientific school developed basic programmatic and methodological directions for determining the effectiveness of soil protection crop rotations in stationary long-term studies (CDAVO, F. R-27, op. 20, c. 725, p. 30), in particular, the dependence of the quality of agricultural products (protein, crude gluten, glassiness, mass of 1,000 grains, nature, nitrogen, phosphorus and potassium content) on placement in crop rotation and precursors with the introduction of organo-mineral fertilizers (Kovalenko, 2014b, p. 92), but also optimized water and nutrient soil modes in crop rotation with the use of busy vapors by sainfoin, oat mix and corn for green forage (CDAVO, F. R-27, op. 20, c. 725, p. 130).

The researchers designed effective soil protection technologies for different soil and climatic conditions of Ukraine. For example, they investigated in the Ukrainian Steppe the effectiveness of grain-steam crop rotations, non-polishing cultivation of soil, organo-mineral fertilizers for irrigation conditions, and highproductivity technologies for cultivation of leading crops on irrigated lands (Kovalenko, 2014b, p. 92), focusing on rice, winter wheat, soybeans, vegetables, potatoes, fruits and grapes. Attention was paid to the technology of obtaining two crops in one year (CDAVO, F. R-27, op. 22, c. 128, p. 3). In the Ukrainian Forest Steppe, the effect of the system of soil protection cultivation and organomineral fertilizers in grain-industrial crop rotations on soil fertility and the quality of agricultural products was determined (Kovalenko, 2014b, p. 92), effective 
precursors for winter wheat, winter rye, barley, peas, buckwheat, sugar beets, vegetables and perennial legumes were identified (CDAVO, F. R-27, op. 21, c. 34, p. 16), and the anti-erosion efficiency of wrapping of post-harvest residues was established (CDAVO, F. R-27, op. 21, c. 34, p. 17). In Polissia, the role of sainfoin and clover in the accumulation of biological nitrogen in the soil was determined (CDAVO, F. R-27, op. 21, c. 43, p. 2) and the effectiveness of use of sidereal crop rotations with growing lupine for green fertilizer on dried peat bogs and over-moist mineral soils was investigated (CDAVO, F. R-27, op. 22, c. 514 , p. 41). The researchers determined the most favorable conditions for the implementation of post-harvest crops: mixtures of feed lupine, corn, oats and peas, and established the soil protection efficiency of multicomponent mixtures in post-harvest crops (Kovalenko, 2014a, p. 298).

Vasyl Pastushenko published more than 170 scientific works, including monographs in Ukrainian: Crop Rotations in Collective Farms of Ukraine (1959), Soil Erosion and Control (1961), Crop Rotations in Ukraine (1966; 1972), Intensive Crop Rotations in the Forest Steppe and Polissia (1975) (NA NNT "IZ NAAN", op. 1-1, c. 174 , pp. 162-170). His postgraduate students, including 22 candidates and 2 doctors of agricultural sciences, P. I. Boiko, V. O. Borodan, I. H. Zakharchenko, V. V. Kulbida, H. K. Medvid, and I. G. Predko, among others, significantly expanded and deepened the theoretical and methodological foundations of the development and improvement of soil protection and antierosion technologies for growing crops (Kovalenko, 2014b, p. 93).

The main focus of the research of an experienced and talented scientist, candidate of agricultural sciences Ivan Hryhorovych Zakharchenko (1913-1979) was to establish the nutrient balance in intense crop rotations, which was first initiated on a wide scale in Ukraine (Saiko, Bogovin \& Solodiuk, 2006, pp. 207-209). On the basis on these studies, scientifically sound standards were developed for returning nutrients to the soil to ensure the reproduction process of its fertility. Zakharchenko published more than 120 scientific works, was a co-author of the textbook Agriculture (1965), and supervisor to six candidates of agricultural sciences.

Hryhorii Kalenykovych Medvid (1935-1992), candidate of agricultural sciences, was the school's active follower in the subject of effective soil nutrition of crops. He developed a quantitative and qualitative assessment of the income and expenditure items of nitrogen balance and revealed the effect of agricultural factors on the nitrogen balance in different types of crop rotation (Saiko, Bogovin $\&$ Solodiuk, 2006, pp. 228-229). These studies provided new knowledge about the 
nitrogen-fixing ability of different legumes and their role in nitrogen balance in soil, as well as nitrogen transformation in the soil-plant system. This contributed to establishing a scientific basis for the study of the cycle and balance of nitrogen, phosphorus, potassium, and organic substances using the crop rotation system as the scientific basis for regulating soil fertility in the study of its reproduction. Medvid published more than 45 scientific works, including 'Methodological guidelines for the study of nutrient balance in agriculture' (1974) (Kovalenko, 2014a, p. 299).

Doctor of agricultural sciences Volodymyr Vasylovych Kulbida (19321997) multiplied the achievements of the scientific school. He investigated the effectiveness of soil protection technologies in their intensification and biologization and explained the role of soil protection with post-harvest, post-cultivation and sidereal crops in crop rotations in Polissia, Ukraine (Saiko, Bogovin \& Solodiuk, 2006, pp. 86-87). Kulbida published more than 120 scientific works, among which he co-authored the monograph Intensive Crop Rotations of the Forest Steppe and Polissia (1975).

The research priority of the well-known agricultural scientist, candidate of agricultural sciences Ivan Hryhorovych Predko (1923-1997) was the establishment of effective winter wheat cultivation in the Ukrainian Forest Steppe. In particular, he scientifically substantiated place in crop rotation, precursors, fertilizer system, tillage, and the use of post-harvest crops depending on winter wheat varieties (Saiko, Bogovin \& Solodiuk, 2006, pp. 248-250). This ensured the balance of the crop area under different soil and climatic conditions of Ukraine. On the basis of scientific developments, he recommended the production of a wide crop-rotation system, taking into account different specializations of farms. The scientist was supervisor to five candidates of agricultural sciences and has published more than 180 scientific, methodological and practical works (Kovalenko, 2014a, p. 299).

Candidate of agricultural sciences Volodymyr Oleksandrovych Borodan (19492005) introduced a new field of research as he determined the effectiveness of the biology of crop rotations on the basis of cultivation of sidereal crops, wrapping by-products and application organic fertilizers in different soil and climatic conditions of Ukraine (Boiko, Borodan \& Kovalenko, 2005, p. 10).

The closest and most talented follower of the scientific school, the famous agricultural scientist and doctor of agricultural sciences Professor Petro Ivanovych Boiko (born 1934) has made a significant contribution to the development of 
soil conservation agriculture (Saiko, Bogovin \& Solodiuk, 2006, pp. 31-33). For more than 50 years, he has been researching the effectiveness of various aspects of agricultural soil protection technologies in different soil and climatic conditions in Ukraine (Kovalenko, 2014b, p. 93), in particular, the development of soil protection crop rotations based on the optimization of the structure of sown areas, the use of the best precursors, and the use of biologization measurespost-harvest, post-cultivation and sidereal crops, organic fertilizers and rational cultivation of the soil (Kovalenko, 2016, p. 8).

Professor Boiko was the first to establish the efficient placement of high-yielding grain crops in crop rotations with different saturation of different crop groups. He has proven the importance of crop rotation to increase the yield of highyielding grain crops over unmodified crops and identified the best precursors, their effect on increasing the yield, quality, productivity, economic and energy efficiency (Kovalenko, 2014a, p. 300). For the first time, Boiko carried out a comprehensive agrotechnical assessment of the precursors of high-yielding cereals in connection with the effects of intensification and biologization factors. He revealed the effectiveness of the main aspects of soil protection technologies and weather conditions for the yield and quality of high-yielding grain crops, weediness, damage to diseases and pests, and the state of agrophysical, agrochemical and biological indicators of soil, economic and energy efficiency (Kovalenko, 2014b, p. 93).

Under the guidance of Professor Boiko, a complex basic research to determine the impact of biological factors on soil fertility (phytonematodes, microflora, soil toxicity—allelopathy), crop productivity, fertility and phytosanitary status of soil and crops was carried out for the first time. On the basis of the resarch, ecological factors of soil under the influence of different crops were determined, such as, for example, formation of negative allelopathic effects of soil and plant roots' toxicity in constant cultivation (Kovalenko, 2016, p. 9). In the microbial coenosis of chernozem soils, the researchers determined the reduction of the specific gravity of a small number of soil microorganisms and increase of the species dominant for the corresponding agrophytocenosis, increase in the share of phytotoxic forms with high activity, and decrease in the number of bacteria-activators. Boiko identified the role of maize in controlling phytotoxic nematodes and overcoming soil fatigue, and improving the phytosanitary state of soil and crops (Kovalenko, 2014a, p. 301). The results of the studies contributed significantly to the development of knowledge in agricultural allelopathy and reinforced the important role of crop rotation in overcoming the negative effects of soil fatigue. 
In the 1990s, under Boiko's lead, the researchers of the scientific school were mainly involved in the development of theoretical foundations and ecologically safe soil protection technologies for reproduction of soil fertility. This was achieved through rational land use, creation of models of soil protection systems of agriculture, and the use of high-efficiency fertilizers and land reclamation measures in crop rotation (Kovalenko, 2014b, p. 93). The specified measures ensured high-quality produce and environmental protection. The researchers outlined the important role of perennial legumes, which compensated for $30-50 \%$ of the total nitrogen losses for crop production in crop rotation (NA NNT "IZ NAAN", op. 2, c. 868, p. 141). They also developed dynamic long-term crop rotations for large farms of varied specialization and short-term crop rotations for small farms of narrow specialization, and established ways of reducing the negative impact of incompatibility and self-incompatibility of crops in crop rotations (Kovalenko, 2014b, p. 93). Researchers of the scientific school investigated the effectiveness of alternative farming with limited use or complete exclusion of mineral fertilizers. The maximum use of the biological means of intensification-sidereal, post-harvest and post-cultivation crops, the introduction of organic fertilizers and by-products-resulted in an increase in soil fertility, preserving the environment and obtaining environmentally friendly products (NA NNT "IZ NAAN", op. 2, c. 902, p. 144). The scientific school gained recognition for defining the concept of the development of soil protection and anti-erosion technologies in the Ukrainian Forest Steppe and Polissia, and also for implementing energy-saving and resource-saving soil-protection methods of basic tillage to obtain environmentally friendly products.

On Professor Boiko's suggestion, the researchers of the scientific school started systematic studies on the effective interaction of the basic elements of the system of soil protection agriculture-the factor of crop rotation, different fertilizer systems (biological, organic, organo-mineral with different levels of fertilizer and with plowing into the soil of post-harvest residues, and mineral), shelf and shelfless tillage. Relying on the basic principles of the method, proposed by Boiko, his postgraduate students contributed significantly to the theoretical development and practical implementation of effective soil protection technologies in the Ukrainian Forest Steppe and Polissia. V. F. Kaminskyi, in particular, defined the agrobiological bases of intensification of the cultivation of legumes in crop rotations. M. M. Nazarenko established the efficiency of cultivation of corn for grain in crop rotations in connection with fertilization and tillage. K. M. Vyshniakova justified the use of corn for grain and silage in crop rotation units depending on the density of planting and fertilizer. 
Yu. I. Solohub worked on the biologization of sugar beet cultivation in grain and industrial crop rotations using post-harvest crops and by-products for fertilizer. $\mathrm{O}$. V. Yehorov determined the effectiveness of potato cultivation in short-term crop rotations under different fertilizer systems. M. H. Furmanets established the optimal placement of winter wheat in short-term crop rotations using different precursors and fertilizers. O. Ye. Koretskyi and L. S. Kvasnitska developed the biologization of the cultivation grain crops in short-term crop rotations after a different legume (Kovalenko, 2016, p. 10).

In the 2000s, under the guidance of Professor Boiko, the researchers of the scientific school paid considerable attention to the development of farming systems that would ensure rational use of agricultural land, reproduction of soil fertility, protection against wind and water erosion, increased productivity, and the stability of agrocenosis (Kovalenko, 2014b, p. 94). In particular, the researchers determined the effectiveness of anti-erosion tillage across the slopes with mulching and alternation of cultivation of industrial crops and perennial grasses in stripes on the slopes (NA NNT "IZ NAAN", op. 2, c. 938, p. 141). They improved the systems of crop rotations of varying length, which provided the production of competitive products and preservation of soil fertility in different soil and climatic conditions in the Ukrainian Forest Steppe and Polissia. The researchers created a database for scientific assessment of crop rotations and structure of sown areas with the help of software, focusing mainly on the substantiation of theoretical, methodological and practical foundations of optimization of the structure of sown areas and crop rotations due to soil fertility control, quantity and quality of crop, and economic and energy efficiency of technologies of cultivation of crops (Kovalenko, 2014b, p. 94). The effectiveness of maximum involvement of renewable local organic resources, biologicals and growth promoters was established to ensure high-quality production and environmental protection (NA NNT “IZ NAAN", op. 2,c. 972, p. 135). The researchers also developed and implemented efficient crop rotations of different lengths with optimal placement of crops, adapted to the soil and climatic conditions of Ukraine and the specialization of farms.

The scientists developed the basic models of resource-saving and energy-saving soil protection for ecologically safe farming systems based on accelerated optimization of degrading agricultural lands. They also defined the directions of soil formation under the conditions of agricultural intensification (Kovalenko, 2014 b, p. 94). Also, the scientific basis of constructing grain-grass-industrial crop rotations, anti-erosion tillage, agricultural soil protection systems was 
established to provide soil protection from erosion, effective use of soil and climatic resources for intensification and increasing the production of quality agricultural products in Ukrainian farms (Kovalenko, 2014a, pp. 193-194). The scientists developed tillage systems for specialized long- and short-term crop rotations and use of organic fertilizers, crop by-products, post-harvest and postcultivation of the remains of crops. To improve the phytosanitary condition of soil and crops, alternation of different biological groups of crops was proposed (NA NNT "IZ NAAN", op. 2, c. 993, pp. 56). The researchers developed scientific foundations and practical recommendations for the introduction of crop rotation system for preserving soil fertility and producing competitive products in Ukraine.

Professor Boiko has published more than 290 scientific-methodological works, among which the following are individually by him: the monograph Corn in Intensive Crop Rotations (1990) and academic publications 'The role of crop rotations in intensive agriculture' (1986), and 'Biological and ecological role of crop rotations in agriculture' (1990) (Kovalenko, 2014b, p. 94). He is the co-author of the textbook Environmental Problems of Agriculture (2010); the monograph Crop Rotations and Fertility of the Black Soil of the Left-Bank Forest Steppe (2019), and the academic publications 'The impact of precursors and crop rotations on the productivity of basic grain crops in Ukraine' (1972), 'Crop rotations in intensive agriculture' (1974), 'Proper crop rotations-a pledge of high yield' (1975), 'Effective land use' (1976), 'Crop rotations - the basis of agricultural intensification' (1985), 'Sustainability of agriculture: problems and solutions' (1993), 'The scientific basis of the management of grain production' (1994), and 'The scientific basis of agro-industrial production in the Forest Steppe of Ukraine' (2004, 2010). He has developed 'Methodological recommendations for the optimal ratio of crops in crop rotations in different soil and climatic zones of Ukraine' (2008), 'Modern systems of fertilization of crops in crop rotations of different length in the main soil and climatic zones of Ukraine' (2008), and 'Modern systems in agriculture and crop production technologies' (2012). The defining feature of the Boiko's scientific works was the revelation of the importance of the multifaceted aspects of soil protection technologies in agriculture of different soil and climatic conditions of Ukraine. Professor Boiko has co-authored the recommendation 'Crop rotations in Ukrainian agriculture' (2002), which is of considerable practical importance for the development of agricultural soil protection. He developed crop rotations of varying length in the zonal section: for the Steppe, Forest Steppe, Polissia, Carpathians, Transcarpathia, the Crimean Lowland, as well as for irrigated and drained lands, highlighting crop rotations 
with vegetable and soil protection crop rotations, optimization of structure of sown areas and the crop rotations system using mathematical modeling. In 2015, he co-authored scientific and methodological recommendations 'Optimization of crop rotation systems and providing scientific support for their development in agro-industrial production' and 'Introduction of short-term crop rotations in organic farming', which contributed to improving the efficiency of sciencebased agriculture (Kovalenko, 2016, p. 11). These scientific publications have developed promising soil protection and anti-erosion technologies for different soil and climatic conditions of Ukraine.

Since the 1970s, the researchers of the scientific school have enjoyed fruitful cooperation with scientists in Lithuania, Moldova and Russia. Together with Professor A. P. Tindzhiulis from the Lithuanian Agricultural Research Institute, they confirmed the effectiveness of soil protection crop rotations with the cultivation of winter rye, barley, oats, and perennial herbs. Such soil protection crop rotation provided an increase in the anti-erosion effect and soil fertility in Lithuania (Vorobiov \& Zalialov, 1988, pp. 98-99). The use of better precursors for grain crops, biological measures-post-harvest, post-cultivation and sidereal crops, organic fertilizers and rational tillage-have ensured an increase in the yield, quality, productivity, economic and energy efficiency of agricultural production (Vorobiov \& Zalialov, 1988, p. 107). Together with Professor P. T. Kibasov from the Moldovan Research Institute of Breeding, Seeds Production and Agrotechnology of Crops, the effectiveness of soil protection systems in agriculture was confirmed (Kovalenko, 2011, p. 27) — namely, in 78\% of the Moldova farms that needed introduction of these systems, they used grain-grass crop rotations with organic fertilizer, cultivated sidereal, post-harvest and post-cultivation crops, and anti-erosion tillage (Kovalenko, 2011, p. 32). In cooperation with Professor S. A. Vorobiov from the Moscow K. A. Timiriaziev Agricultural Academy, they confirmed the effectiveness of wrapping post-harvest remnants of perennial legumes to improve the physical properties of soil and increase soil fertility (Vorobiov \& Zalialov, 1988, p. 11). By wrapping the root and surface post-cultivation remnants of clover and the application of organic fertilizers, the anti-erosion effect and the quantity and quality of environmentally friendly agricultural products was increased (Vorobiov \& Zalialov, 1988, pp. 12-13). At the beginning of the 21 st century, the experience of Ukrainian scientists in applying soil protection technologies continues to be widely used in the above countries. In particular, systems of energy-saving and resource-saving soil protection tillage to increase soil fertility were introduced and the production of environmentally friendly agricultural products was increased (Kovalenko, 2014a, p. 302). On the basis of 
the developed direction of agricultural allelopathy about chemical interaction of crops, the researchers introduced scientifically based crop rotations, which ensured overcoming of the negative phenomenon of soil fatigue and improvement of the environment (Kovalenko, 2011, p. 38).

Thus, the Vasyl Pastushenko scientific school for the development of soil protection and anti-erosion technologies made a significant contribution to the development of not only domestic but also global agrarian science. The extensive years of experience and in-depth knowledge, the traditions and research practices continue to exist, define and expand the scientific directions of environmental protection in Ukraine and elsewhere in the world. The creative activities of the scientific school are augmented by its followers who have preserved its intellectual climate and extended current developments by means of advanced technology.

\section{References}

Boiko, P. I. (2003), 'Pastushenko Vasyl Onufriiovych (1907-1999),' in Vchenigruntoznavtsi, ahrokhimiky, zemleroby, Kyiv: Ahrarna nauka, vol. 8, pp. 280-281.

Boiko, P. I.; Borodan, V. O. \& Kovalenko, N. P. (2005), 'Ekolohichno zbalansovani sivozminy-osnova biolohichnoho zemlerobstva' [Ecologically balanced crop rotations are the basis of biological agriculture], Visnyk ahrarnoi nauky, no. 2, pp. 9-13.

CDAVO, F. R-27, op. 20, c. 234, 442, 725, Centralnyi derzhavnyi arkhiv vyshchykh orhaniv vlady ta upravlinnia Ukrainy, Ukrainian State Archive of the Highest Authorities and Management.

CDAVO, F. R-27, op. 21, c. 34, 43, Centralnyi derzhavnyi arkhiv vyshchykh orhaniv vlady ta upravlinnia Ukrainy, Ukrainian State Archive of the Highest Authorities and Management.

CDAVO, F. R-27, op. 22, c. 128, 514, Centralnyi derzhavnyi arkhiv vyshchykh orhaniv vlady ta upravlinnia Ukrainy, Ukrainian State Archive of the Highest Authorities and Management.

Khramov, Yu. O. (2008), 'Naukovi shkoly v NAN Ukrainy' [Academic schools in Ukraine], Nauka ta naukoznavstvo [Science and Science of Science], no. 4, pp. 122-133.

Kovalenko, N. P. (2011), Naukovo-orhanizatsiina diialnist Koordynatsiino-metodychnoi rady UASHN, MSH URSR, PV VASHNIL ta UAAN z problem sivozmin u systemakh zemlerobstva Ukrainy (1956-2010 rr.) [Scientific-organizational activity of coordinating-methodological advice of UAAS, MA of Ukraine, SS AAASL and UAAS, on the problems of crop rotations in the systems of agriculture of Ukraine (1956-2010)], Kyiv: FOP Korzun, D.Yu. 
Kovalenko, N. P. (2014a), Stanovlennia ta rozvytok naukovo-orhanizatsiinykh osnov zastosuvannia vitchyznianykh sivozmin u systemakh zemlerobstva (druha polovyna XIXpochatok XXI st.): monohrafia [Origins and development of scientific-organizational bases of application of home crop rotations in agricultural systems (from the second half of the 19 th to the beginning of the 21 st century): A monograph], Kyiv: TOV "Nilan-LTD".

Kovalenko, N. P. (2014b), Rozvytok nauky pro sivozminy u systemakh zemlerobstva Ukrainy v konteksti diialnosti naukovoi shkoly NNTs "Instytut zemlerobstva NAAN" [Evolution of the discipline of crop rotations in agricultural systems of Ukraine in the context of activity of the scientific school of NSC "Institute of Agriculture of NAAS”], Gileya, vol. 84, pp. 92-95.

Kovalenko, N. P. (2016), Profesor Boiko Petro Ivanovych: biobibliohrafichnyi pokazhchyk naukovykh prats za 1966-2016 roky [Professor Boiko, Petro Ivanovich: biobibliographical index of scientific works for 1966-2016], Kyiv: TOV “Nilan-LTD”.

Kovalenko, N. P. (2018), 'Priorytetni napriamy diialnosti naukovoi shkoly z udoskonalennia teoretychnykh i metodolohichnykh osnov zroshuvanoho zemlerobstva v Ukraini' [Priority directions of the activity of the scientific school on improvement of theoretical and methodological foundations of irrigated agriculture in Ukraine], Chasopys ukrainskoi istorii, vol. 37, pp. 132-138. https://doi.org/10.17721/2522-4611

Mykulinskyi, S. R. \& Yaroshevskyi, M. H. (1977), Shkoly v nauke [Schools in science], Moskva: Nauka.

NA NNT “IZ NAAN”, op. 1-1, c. 174, pp. 134-175, Naukovyi arkhiv Natsionalnoho naukovoho tsentru "Instytut zemlerobstva NAAN" [Scientific Archives of the National Scientific Centre "Institute of Agriculture of NAAS”].

NA NNT “IZ NAAN", op. 2, c. 868, p. 365; c. 902, p. 831; c. 938, p. 364; c. 972, p. 316; c. 993, p. 174, Naukovyi arkhiv Natsionalnoho naukovoho tsentru "Instytut zemlerobstva NAAN" [Scientific Archives of the National Scientific Centre "Institute of Agriculture of NAAS”].

Onopriienko, V. I. \& Tkachenko, V. M. (2010), Istoriia ukrainskoi nauky [The history of Ukrainian science], Kyiv: Varta.

Pastushenko, V. O. (1952), Pravylnye travopolnye sevooboroty v kolkhozakh Ukraynskoi SSR [Correct grass-field crop rotations in collective farms of Ukrainian SSR], Kyiv: Yz-vo KHU ym. T.H. Shevchenko.

Pastushenko, V. O. (1958), Pro pravylni sivozminy v kolhospakh Ukrainskoi RSR [About correct crop rotations in the collective farms of Ukrainian SSR], Kyiv: UASHN.

Pastushenko, V. O. (1959), Sivozminy v kolhospakh Ukrainy: monohrafia [Crop rotations in collective farms in Ukraine: A monograph], Kyiv: UASHN.

Pastushenko, V. O. (1966), Sivozminy na Ukraini: monohrafiia [Crop rotations in Ukraine: A monograph], Kyiv: Urozhai. 
Pastushenko, V. O. (1972), Sivozminy na Ukraini: monohrafiia [Crop rotations in Ukraine: A monograph], Kyiv: Urozhai.

Saiko, V. F.; Bogovin, A. V. \& Solodiuk, N. V. (2006), Zolotyi fond NNC "Instytut zemlerobstva UAAN": dovidkovo-bibliografichne vydannja [Gold Fund of NSC "Institute of agriculture of UAAS": A reference and bibliographic edition], Kyiv: EKMO.

Skorodumov, O. S.; Pastushenko, V. O. \& Dunaievskyi, V. N. (1961), Eroziia gruntiv i borotba z neiu: monohrafia [Soil erosion and control: A monograph], Kyiv: UASHN.

Vergunov, V. A.; Borodai, I. S.; Kovalenko, N. P.; Kovalenko, S. D. \& Shchebetyuk, N. B. (2016), Kalendar znamennykh i pamiatnykh dat $v$ istorii silskohospodarskoi doslidnoi spravy Ukrainy na 2017 rik [Calendar of memorable dates in the history of agricultural research in Ukraine for 2017], Kyiv: FOP Korzun, D. Yu.

Voloshchuk, M. D.; Petrenko, N. I. \& Yatsenko, S. V. (2014), Eroziia gruntiv Ukrainy: evoliutsiia teorii ta praktyky: monohrafiia [Erosion of soils of Ukraine: evolution of theory and practices: A monograph], Kyiv: TOV "Nilan-LTD".

Vorobiov, S. A. \& Zalialov, F. K. (1988), Otchet o rezultatakh nauchnykh issledovanyi po probleme "Razrabotka nauchnykh osnov sevooborotov $v$ intensivnom zemledelii" [Report on the results of scientific research on the problem "Development of the scientific foundations of crop rotation in intensive farming"], Moskva.

Nataliia Kovalenko is a chief researcher of the science sector at the Institute of History of Agrarian Science, Education and Technology of the National Scientific Agricultural Library of the National Academy of Agrarian Sciences of Ukraine. She received her doctoral degree in historical sciences in 2016. Her scientific activity is aimed at determining the scientific-organizational and conceptual foundations of the formation and development of agricultural research in Ukraine and in the world, exploring the development of agrarian science in the global context, education and technology contributed by research institutions and higher educational establishments, scientific schools and centers and well-known Ukrainian scientists and practitionersagrarians in the formation and development of theoretical-methodological and practical foundations of agrarian production in Ukraine. She is the author of more than 280 scientific publications, including 6 monographs, 3 brochures, 3 scientific books, an educational program, 8 collections of documents and materials, 3 methodological recommendations, 2 bio-bibliographical indexes and more than 260 scientific papers published in leading Ukrainian and foreign publications. The main directions of her research are the history of the development of agricultural science schools, the expansion of the 
introduction of innovative technologies in greening agricultural production, the improvement of energy-saving and resource-saving technologies for the production of organic products in Ukraine and the world. 